\title{
Localisation of endothelin like immunoreactivity in adult and developing human gut
}

\author{
C Escrig, A E Bishop, H Inagaki, G Moscoso, K Takahashi, I M Varndell, M A Ghatei, \\ S R Bloom, J M Polak
}

\begin{abstract}
The distribution of immunoreactivity for the potent vasoconstrictor endothelin-1 was studied in adult and developing human gut using antisera to endothelin-1 (1-21) and the $C$ terminus of big endothelin-1. The coexistence of these peptides with other neuropeptides was investigated using comparative immunocytochemistry. Endothelin-1 like immunoreactivity was detected in extracts of adult (range 20$60 \mathrm{fmol} / \mathrm{g}$ wet weight) and fetal $(33 \mathrm{fmol} / \mathrm{g}$ ) gastrointestinal tract and was shown by chromatography to be the predominant isoform of endothelin present in both. It was localised by immunocytochemistry to ganglion cells in the submucous and myenteric plexuses and to scattered nerves, whereas big endothelin-1 like immunoreactivity was found in the submucous plexus only. Colocalisation studies showed immunoreactivity for both endothelin-1 and vasoactive intestinal peptide in the same ganglion cells of the submucous plexus. Although endothelin-1 immunoreactivity was not detected by immunocytochemistry in the fetal human gut until the 32nd week of gestation, big endothelin-1 was found as early as 11 weeks in the developing neural structures and epithelial cells. The latter were shown to be endocrine cells by their immunoreactivity for chromogranin. Our results indicate that endothelin is a neuropeptide found in adult human gut which shows transient expression in endocrine cells during development.
\end{abstract}

Departments of Histochemistry and Medicine, Royal Postgraduate Medical School, Hammersmith Hospital, London

C Escrig

A E Bishop

H Inagaki

K Takahashi

M A Ghatei

S R Bloom

J M Polak

Department of Morbid Anatomy, King's College Hospital, London

G Moscoso

Cambridge Research Biochemicals Ltd,

Northwich, Cheshire

I M Varndell

Correspondence to:

Dr A E Bishop, Department of

Histochemistry, Royal

Postgraduate Medical School

Hammersmith Hospital,

Hammersmith Hosp

Accepted for publication

23 May 1991
Endothelin-1, the first member of a newly discovered mammalian family of biologically active peptides, was originally isolated from the supernatant of cultured porcine endothelial cells. ${ }^{1}$ It is synthesised as a precursor peptide of 203 amino acids, containing a signal sequence, which is subsequently cleaved proteolytically to produce the 38 (human) or 39 (porcine) amino acid intermediate big endothelin-1 (big endothelin-1). This is processed further to the mature 21 amino acid form, endothelin-1. ${ }^{1-5}$ Several isoforms of endothelin-1 have been isolated - endothelin-2 and endothelin-3. ${ }^{23}$ The latest isoform of the endothelin family to be characterised is a 21 amino acid peptide originally isolated from the guinea pig ileum and termed vasoactive intestinal contractor. Vasoactive intestinal contractor differs from endothelin-1 at three positions (positions 4, 6, and 7), and from endothelin-2 at only one position (position 4). In addition, these peptides show structural homology with a group of peptide toxins called sarafotoxins from the venom of a snake, the burrowing asp Attactaspis engaddensis. ${ }^{67}$
Endothelin binding sites are widely distributed, not only in vascular tissues but also in trachea, lung, kidney, gastrointestinal tract, and brain..$^{8-13}$ In addition to its vascular location, there is evidence that endothelin- 1 also occurs in nerve tissue. It was detected by immunocytochemistry in the paraventricular and supraoptic nuclear neurons and their terminals in the posterior pituitary of the pig and rat, ${ }^{14}$ in the neurons of porcine spinal cord, ${ }^{15} 16$ in human dorsal root ganglia, ${ }^{17}$ and in both glia and neurons within the brain. ${ }^{18-20}$ More recently, endothelin-1 immunoreactivity was found in the innervation of the human colon $^{21}$ where its binding sites were localised to nerves, blood vessels, and muscle.

The aims of this study were (a) to determine the patterns of expression of endothelin- 1 and its precursor molecule, big endothelin-1, by immunostaining for both molecular forms in all regions of adult and developing human gut, and (b) to measure the concentrations and molecular forms of endothelin present using radioimmunoassay and chromatography.

\section{Methods}

\section{IMMUNOCYTOCHEMISTRY}

Histologically normal samples of adult stomach $(n=5)$ (body and antrum), duodenum $(n=3)$, jejunum $(n=3)$, ileum $(n=3)$, colon $(n=5)$, and pancreas $(n=4)$ were removed during surgical excision of tumours. Samples of fetal gastrointestinal tract (stomach, small intestine, and large intestine) from fetuses of 8-32 weeks of gestation were obtained after elective terminations of pregnancy or spontaneous abortion. Tissues were fixed immediately in Bouin's solution for four to 18 hours, washed in $30 \%$ (v/v) alcohol, dehydrated through graded alcohols, and embedded in wax. Paraffin sections $(3 \mu \mathrm{m})$ were mounted on poly-L-lysine coated slides $^{22}$ and dried at $37^{\circ} \mathrm{C}$ overnight.

Antibodies for immunocytochemistry were raised in New Zealand white rabbits using endothelin-1 or big endothelin-1 (C terminal 22-38) linked to keyhole limpet haemocyanin with glutaraldehyde (peptide/carrier molecular ratio 20:1) (Cambridge Research Biochemicals, Northwich, UK). Primary immunisation (100 $\mu \mathrm{g}$ of endothelin-1 or big endothelin-1 (C terminal 22-38) per $\mathrm{ml}$ ) was administered in Freund's complete adjuvant and subsequent immunisations were in Freund's incomplete adjuvant. The animals were given booster injections eight times and blood was taken seven days after each immunisation.

Immunocytochemistry was carried out using the avidin-biotin complex method. ${ }^{23}$ After 
dewaxing, the sections were immersed in methanol containing $0.3 \% \quad(\mathrm{v} / \mathrm{v})$ hydrogen peroxide, rehydrated, and incubated for 30 minutes with normal goat serum (1:20). Antisera to endothelin-1 (RPMS ref no 2020; dilution $1: 2000)$ and big endothelin-1 (RPMS ref no 2051; dilution 1:3000: RPMS ref no 20561 : 1000) (CRB) were applied overnight at $4^{\circ} \mathrm{C}$ in a moist atmosphere. After washing in $0.01 \mathrm{~mol} / \mathrm{l}$ phosphate buffered normal saline, $\mathrm{pH} 7 \cdot 2$ (PBS), the sections were incubated for 30 minutes with biotinylated goat anti-rabbit IgG (Vectastain Elite Kit, Vector Laboratories, Bretton, UK) diluted 1:400 with PBS at room temperature. Following further washing, they were incubated with avidin-biotin peroxidase complex (Vectastain Elite Kit) diluted 1:80 in PBS for 30 minutes at room temperature. The sites of peroxidase activity were visualised by incubation in a solution containing $25 \mathrm{mg}$ of 3-amino-9 ethylcarbazole (Sigma Chemicals, Poole, UK) dissolved in $10 \mathrm{ml}$ of $\mathrm{N}, \mathrm{N}$-dimethylformamide (Sigma Chemicals) and added to $100 \mathrm{ml}$ of $0.02 \mathrm{~mol} / \mathrm{l}$ acetate buffer, $\mathrm{pH} 5 \cdot 2$ (sodium acetate $0.2 \mathrm{~mol} / \mathrm{l}$, acetic acid $0.2 \mathrm{~mol} / \mathrm{l}$ ), and $40 \mu \mathrm{l}$ of $30 \%$ $(\mathrm{v} / \mathrm{v})$ hydrogen peroxide. Sections were counterstained in Mayer's haemalum (BDH Limited, Eastleigh, UK) washed in tap water, and mounted in Hydromount (National Diagnostics UK Ltd, Bucks, UK). The specificity of the antiserum against endothelin-1 was confirmed by incubation of sections with antiserum preabsorbed with synthetic human endothelin-1 (CRB), endothelin-2 (Peninsula Labs), endothelin-3 (Nova Biochem, Nottingham, UK), big endothelin-1 (22-38), sarafotoxin S6b, sarafotoxin S6c (Peninsula Labs), and vasoactive intestinal contractor (Peptide Institute, Osaka, Japan) $(1 \mathrm{nmol} / \mathrm{ml}$ of diluted antiserum). Only incubation with endothelin-1 quenched the immunostaining. In addition, endothelin-1 antiserum was absorbed with synthetic vasoactive intestinal peptide (Peninsula Labs) $(10 \mathrm{nmol} / \mathrm{ml}$ ) to test for possible cross reactivity. No diminution of immunostaining intensity was seen. The specificity of the antisera against big endo-

Figure 1: Endothelin-1 like immunoreactivity in the submucous plexus of human adult duodenum. (Original magnification $\times 500$.)
Characteristics of antisera used in colocalisation studies

\begin{tabular}{lrll}
\hline Antigen & Ref no & Source & Dilution \\
\hline Vasoactive intestinal peptide & 652 & HH & $1: 10000$ \\
Neuropeptide Y & 1101 & HH & $1: 2000$ \\
Calcitonin gene related peptide & 1204 & HH & $1: 2000$ \\
Substance P & 1651 & HH & $1: 5000$ \\
Chromogranin & 1981 & Hybritech & $1: 1000$ \\
Protein gene product 9.5 & 1648 & Ultraclone & $1: 4000$ \\
\hline
\end{tabular}

HH=Hammersmith Hospital; Ultraclone, Cambridge, UK;

Hybritech, Bingham, Nottingham, UK.

with antiserum preabsorbed with synthetic human big endothelin-1 (Peninsula Labs).

Immunostaining with antiserum 2051 could be quenched by addition of big endothelin- 1 at a concentration of $0.1 \mathrm{nmol} / \mathrm{ml}$ diluted antiserum but only partial absorption of the immunostaining with antiserum 2056 could be obtained. Neither antiserum was affected by addition of endothelin-1 at a concentration of $10 \mathrm{nmol} / \mathrm{ml}$. Negative controls included the use of nonimmune serum instead of the primary antiserum or omission of one of the steps in the avidinbiotin complex procedure.

In the adult gut, the possible coexistence of endothelin with neuropeptides was determined using pairs of serial wax sections $(3 \mu \mathrm{m})^{24}$ immunostained with antisera to endothelin-1 and the major gut neuropeptides - vasoactive intestinal peptide (VIP), neuropeptide Y (NPY), calcitonin gene related peptide (CGRP), and substance P (SP) (see Table I for details). The specificities of the antisera to VIP, NPY, CGRP, and SP, have been reported previously. ${ }^{25}$ In order to identify cells in the developing gut, a similar procedure was followed using antisera to chromogranin and protein gene product $9 \cdot 5$, gastrin, glucagon, gastric inhibitory polypeptide, secretin, somatostatin-14 and 5-hydroxytryptamine (see Table I).

\section{RADIOIMMUNOASSAY AND CHROMATOGRAPHY}

For radioimmunoassay, pooled samples of adult stomach (antrum and fundus) and rectum and fetal small intestine ( 17 weeks of gestation) were extracted by boiling in a 10 fold volume of $0.5 \mathrm{~mol} / \mathrm{l}$ acetic acid for 10 minutes. ${ }^{26}$ The supernatant was re-extracted using Sep-Pak C18 cartridges (Water Associates, MA, USA) and endothelin like immunoreactivity eluted with $2 \mathrm{ml}$ of $60 \%(\mathrm{v} / \mathrm{v})$ acetonitrile/water containing $0.026 \mathrm{~mol} / \mathrm{l}$ ammonium acetate. The eluate was dried in a Savant vacuum centrifuge and the resulting pellet reconstituted with buffer $(60$ $\mathrm{mmol} / \mathrm{l}$ phosphate buffer, $\mathrm{pH} 7 \cdot 4$, containing $7 \mathrm{mmol} / 1$ sodium azide and $0.3 \%(\mathrm{w} / \mathrm{v})$ bovine serum albumin). The recovery of endothelin-1, -2 , and -3 , which were added to tissues before boiling, was $>80 \%$. The antibody to endothelin-1 used for radioimmunoassay was obtained from a subsequent bleed of an immunoresponsive rabbit $^{27}$ which gave increased sensitivity. The assay could thus detect changes of $0.05 \mathrm{fmol} /$ assay tube with duplicate tubes at $95 \%$ confidence. The cross reactions with big endothelin (1-38) (Nova Biochem, Nottingham UK), endothelin-2 and endothelin-3 (Peptide Institute, Mono-shi, Japan) were $0 \cdot 1 \%, 60 \%$, and $70 \%$ respectively. The intra- and interassay 


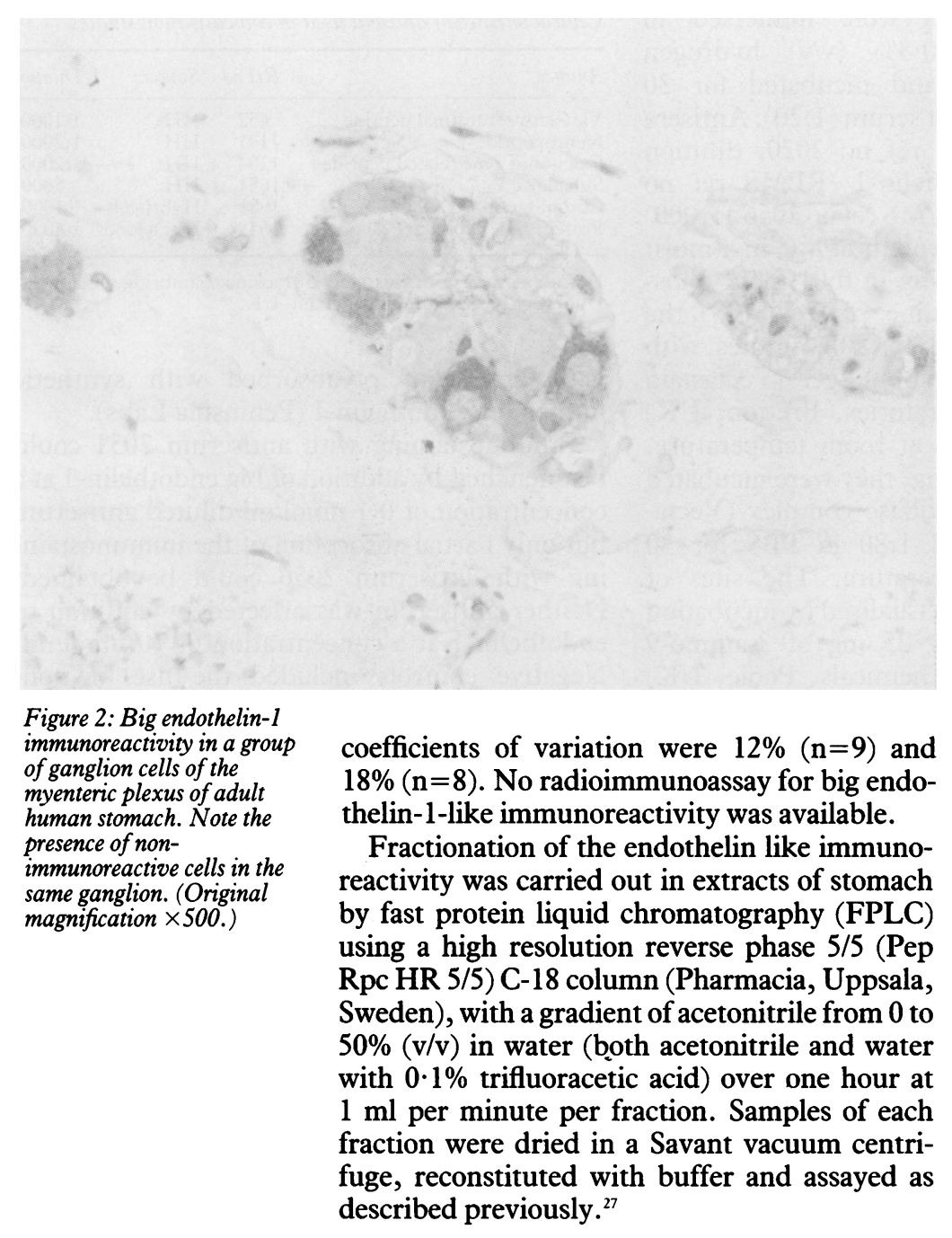

\section{Results}

\section{IMMUNOCYTOCHEMISTRY}

\section{Adult gut}

In the adult gut, numerous endothelin-1immunoreactive nerve cell bodies were seen in both submucous (Fig 1) and myenteric ganglia
(Fig 2) in all regions examined. The immunoreactivity, localised to the cytoplasm, had a granular appearance. In the submucosa, groups of immunoreactive ganglion cells were mainly found just under the muscularis mucosae or close to the circular muscular layer. In the myenteric ganglia, almost all of the reactive cell bodies were large and ovoid and were at the periphery of the ganglion. Few, scattered immunoreactive nerve fibres were seen. No glial cells showed positive immunostaining and no immunoreactivity was detected in cells of the mucosal epithelium. About $80 \%$ of neuronal cells of the submucous plexus and $10 \%$ of the myenteric plexus showed endothelin-1 immunoreactivity. Only weak, inconsistent immunostaining of endothelium was obtained. Immunostaining with both antisera to big endothelin-1 gave positive results only in the submucous plexus, where about half of the ganglion cells were immunostained. No immunoreactive nerve fibres could be detected.

Pairs of serial sections immunostained for endothelin-1 and VIP, NPY, CGRP, or SP showed positive immunostaining in both plexuses, but only VIP was found to be colocalised with endothelin-1 (Fig 3). Most endothelin immunoreactive nerve cell bodies showed colocalisation with VIP in the submucous plexus.

\section{Developing gut}

In the developing gut, immunoreactivity for endothelin-1 could not be shown until the 32nd week of gestation, when it was found only in neural structures. In contrast, big endothelin-1 (ref no 2056) was localised to the submucous and myenteric plexuses of the stomach and small (Fig 4) and large intestine in fetuses at 11 weeks of gestation. These developing structures were identified as neural by their immunoreactivity for protein gene peptide 9.5 in serial sections. A second antiserum against big endothelin-1 (ref no 2051), raised in a different rabbit from 2056 with the same antigen and immunisation methods, showed the presence of big endothelin-1 like immunoreactivity in cells of the mucosal epithelium of the small intestine only (Fig 5) from 11 weeks of gestation. These cells
Figure 3: Serial $3 \mu \mathrm{m}$ sections immunostained for (A) vasoactive intestinal polypeptide and $(B)$ endothelin-1. Colocalisation of the two peptides can be seen. (Original magnification $\times 400$.)

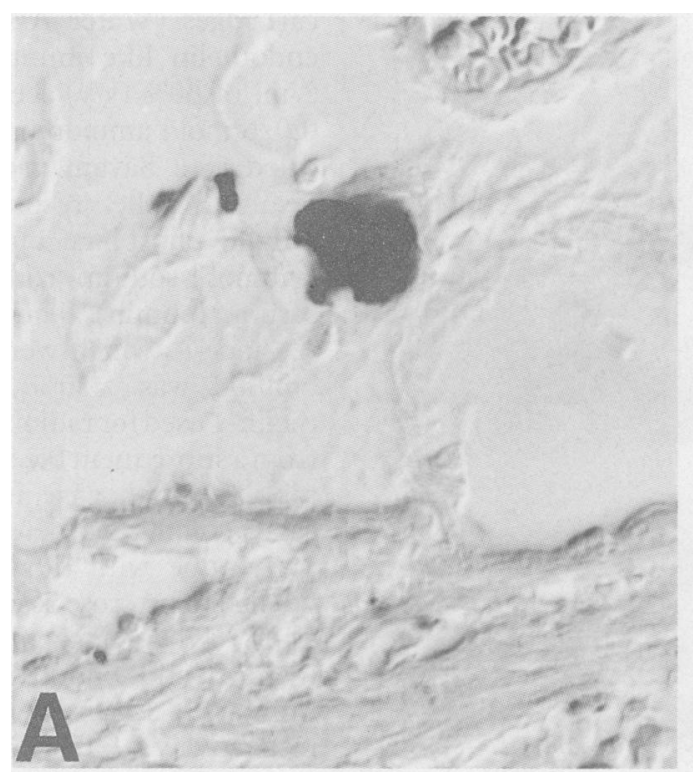


Figure 4: (A) Big endothelin-1

immunoreactivity (detected with antiserum ref no 2061 in submucous and myenteric plexuses in a human fetal small intestine (17 weeks' gestation). (Original magnification $\times 125$.) (B) Big endothelin-1 immunoreactivity in the same preparation as above. Note the presence of nerve fibres ascending towards the villi. (Original magnification $\times 310$.)
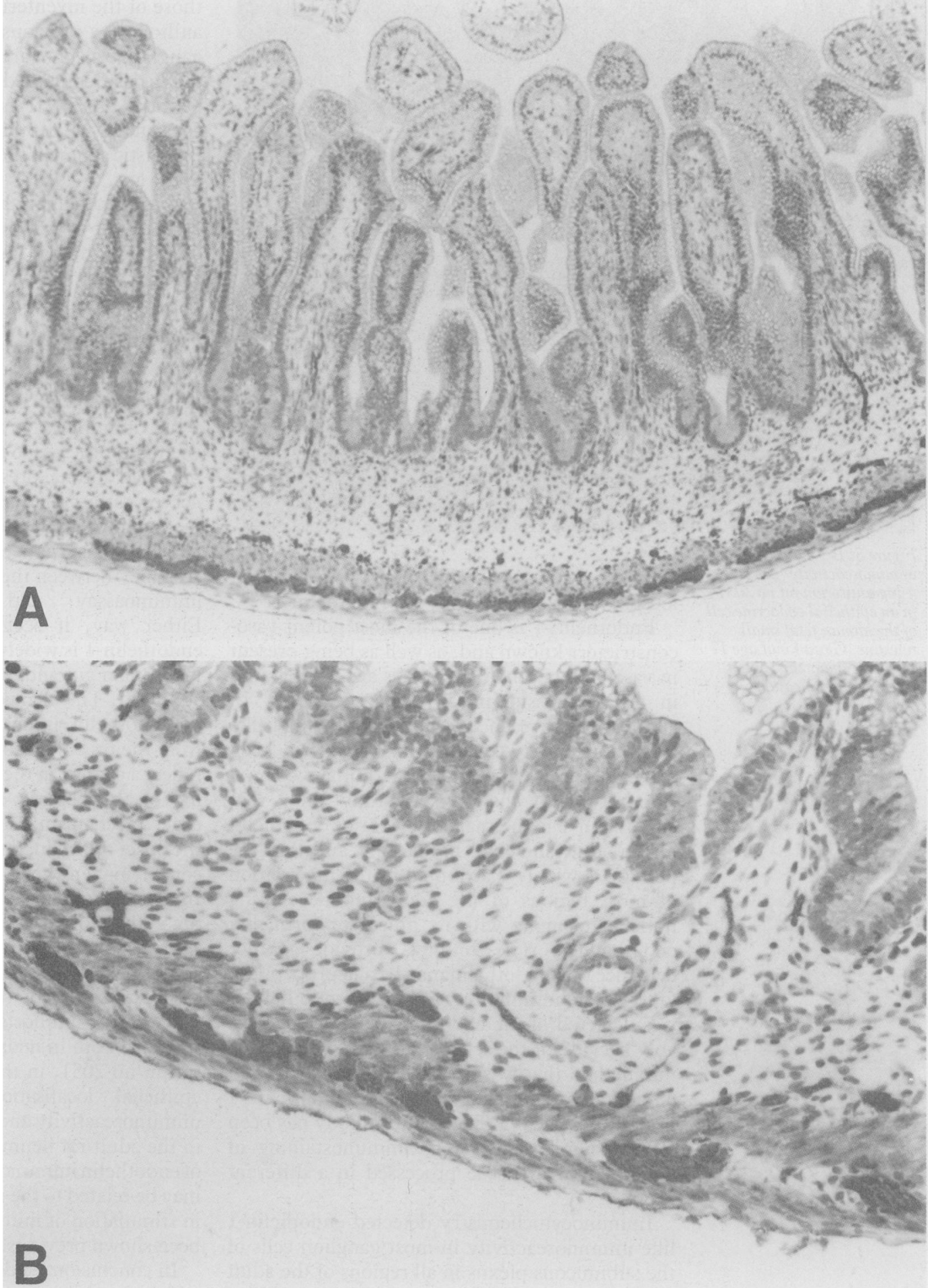

had the appearance of neuroendocrine cells and were identified as such by immunostaining of chromogranin in serial sections. The frequency of these immunoreactive epithelial cells seemed to increase as gestation proceeded, reaching a peak at around 21 weeks, and they were still present in the oldest fetal gut examined (32 weeks' gestation).

\section{Radioimmunoassay and chromatography}

Endothelin like immunoreactivity was detected in adult human stomach $(60 \mathrm{fmol} / \mathrm{g}$ wet weight $)$ and rectum $(20 \mathrm{fmol} / \mathrm{g})$ and fetal small intestine $(33 \mathrm{fmol} / \mathrm{g})$. FPLC of adult stomach extracts showed three peaks in the positions of the three isoforms of endothelin (Fig 6). The peak for endothelin-1 was slightly greater than that for endothelin-2 while the smallest peak corresponded to the position of endothelin-3. The chromatograph of extracts of fetal small intestine showed only one major peak for endothelin-1 and a much smaller one at the position of endothelin-3 (Fig 7).

\section{Discussion}

This study aimed to determine the presence and localisation of endothelin-1, a newly discovered polypeptide, in the adult and developing human gut using immunocytochemical and biochemical techniques and, with immunocytochemistry, to 


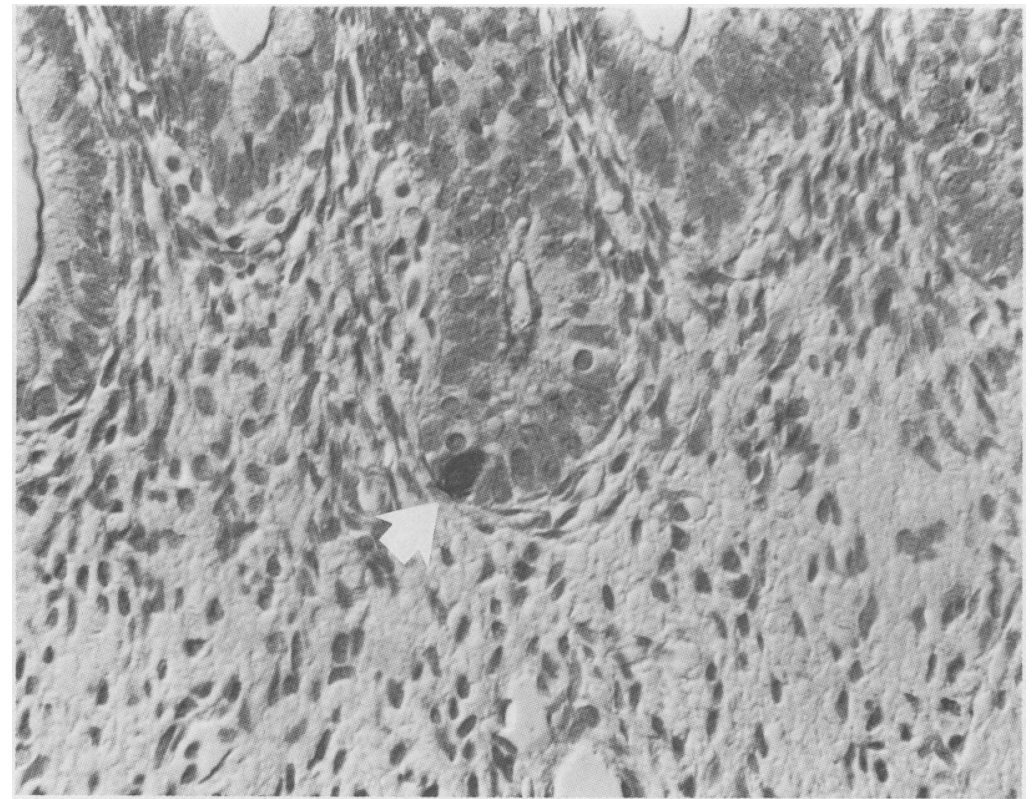

Figure 5: Big endothelin-1 immunoreactivity (detected using antiserum ref no 2051 ) in an epithelial endocrine cell of the human fetal small intestine. Gestational age 17 weeks. (Nomarski's optics, original magnification $\times 310$.)

localise its precursor form, big endothelin-1.

Endothelin-1 is one of the most potent vasoconstrictors known and, as well as being present in vascular endothelium, ${ }^{1}$ it has also been found in nervous tissue in different species. ${ }^{1420}$ In addition, the presence of both endothelin-1 like immunoreactivity and binding sites has been detected recently in the adult human colon. ${ }^{21}$ The results of the present study show that endothelin-1 is the major isoform of endothelin in the adult and fetal human gut and that the peptide is widely distributed in the innervation of most regions of the adult and developing human gut along with its precursor form, big endothelin-1. The findings provide further evidence that endothelin may be a neuropeptide. Only weak immunoreactivity for endothelin-1 was detected in the endothelium. This is probably because of the selection of a tissue processing method that was optimal for demonstration of neural rather than endothelial endothelin-1 immunoreactivity. The same antibody has been found to give satisfactory immunostaining of endothelium in tissue processed in a different way. ${ }^{21}$

Immunocytochemistry detected endothelin-1 like immunoreactivity in most ganglion cells of the submucous plexus in all regions of the adult human gastrointestinal tract and in about $10 \%$ of

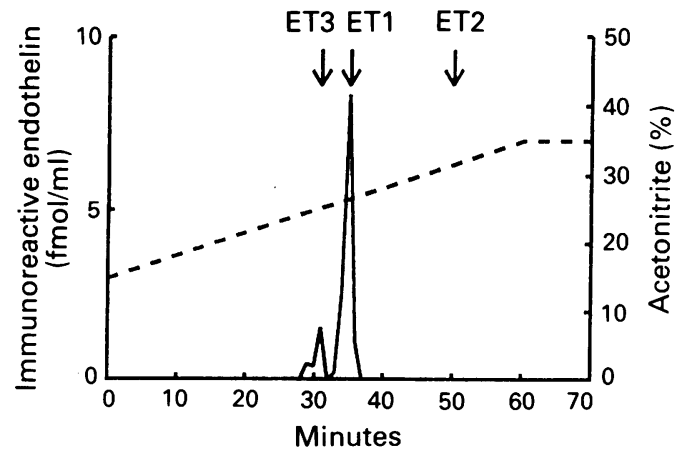

Figure 6: Fast protein liquid chromatography of endothelin like immunoreactivity in extracts of human stomach. ETI, ET2, and ET3 indicate the elution positions of endothelin-1, 2 and 3 , respectively. those of the myenteric plexus. As shown by the authors in a previous study, ${ }^{21}$ most submucosal ganglion cells that are immunoreactive for endothelin also contained VIP, a major gut neuropeptide. Since VIP is a potent vasodilator, this coexistence of peptides suggests a possible antagonistic action in the control of local blood flow in the gut.

Big endothelin-1 like immunoreactivity was detected by immunocytochemistry in the developing human gut as early as 11 weeks of gestation. Although radioimmunoassay showed the presence of endothelin-1 like immunoreactivity in the fetal small intestine at 17 weeks' gestation, it was not detected in nerves until the 32nd week of gestation. Radioimmunoassay detected both endothelial and neural endothelin1 like immunoreactivity but, for immunocytochemistry, the tissue processing method selected provided optimal preservation of endothelin- 1 in nerves rather than endothelium. Thus, endothelin-1 may occur in endothelium earlier than in nerves. This may explain the apparent discrepancy between the results obtained by radioimmunoassay and immunocytochemistry. Either way, it seems that the precursor of endothelin-1 is widely expressed in the developing human gut and only to a lesser extent in the adult gut. The change in the predominant form of endothelin immunoreactivity in the fetus, from the precursor to mature endothelin-1, may reflect a change in the post-translational processing of the peptide during development. The exact mechanism causing the switch, possibly the onset of production or activity of a particular converting enzyme, remains to be explained. Immunoreactivities for both endothelin-1 and big endothelin-1 were localised to neural structures in the adult human gut but no immunoreactivity was observed in the mucosal layer. This contrasted with the results obtained in the fetal gut where immunostaining for big endothelin-1 was seen both in neural plexuses and, with antiserum no 2051, in the mucosal epithelium. An epithelial localisation for both endothelin immunoreactivity and mRNA has been reported in the adult rat ileum and colon. ${ }^{27}$ The presence of endothelin immunoreactivity in the epithelium may be related to the reported role of the peptide in stimulation of mitogenesis in vitro, which has been shown previously in different systems. ${ }^{28-30}$

In conclusion, endothelin-1 is a neuropeptide which, in addition to its endothelial localisation,

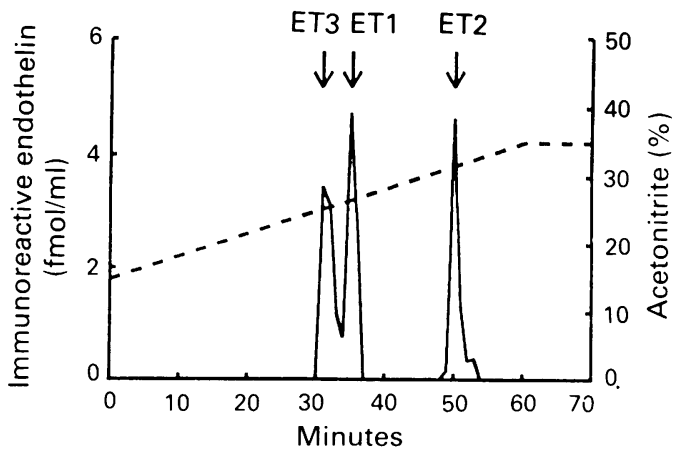

Figure 7: Fast liquid chromatography of endothelin like immunoreactivity in extract of human fetal ( 17 weeks' gestation). Abbreviations as for Figure 6. 
has an extensive distribution in most regions of the human gastrointestinal tract. Furthermore, in humans, certain isoforms of endothelin may operate as specific growth factors in the epithelium of the developing gut in early fetal life.

1 Yanagisawa M, Kurihara H, Kimura S, Tomobe Y, Kobayashi M, Mitsui Y, et al. A novel potent vasoconstrictor peptide produced by vascular endothelial cells. Nature (Lond) 1988; 322: 411-5.

2 Yanagisawa M, Inoue A, Ishikawa T, Kasuya Y, Miyauchi T Goto $\mathrm{K}$, et al. Primary structure, synthesis, and biological Gctivity of rat endothelin, an endolium, and bive activity of rat endothelin, an endothelium-derived vaso6964-7.

Inoue A, Yanagisawa M, Kimura S, Kasuya Y, Yiyanchi T, Goto $\mathrm{K}$, et al. The human endothelin family: three structurally and pharmacologically distinct isopeptides predicted by three separate genes. Proc Natl Acad Sci USA 1989; 86: 2863-7.

4 Saida K, Mitsui Y, Ishida N. Novel peptide, vasoactive intestinal contractor, of a new (endothelin) peptide family. F Biol Chem 1989; 264: 14613-6.

5 Yanagisawa $M$, Masaki T. Endothelin, a novel endotheliumderived peptide. Pharmacological activities, regulation, and possible roles in cardiovascular control. Biochem Pharmacol 1989; 38: 1877-83.

6 Kloog Y, Ambar I, Sokolowsky M, Kochva E, Wollberg Z, Bdolah A. Sarafotoxin a novel vasoconstrictor peptide: phosphoinositide hydrolysis in rat heart and brain. Science 1988; 242: 268-70

7 Bdolah A, Wollberg Z, Fleminger G, Kochwa E. SRTX-d a new native peptide of the endothelin/sarafotoxin family FEBS Lett 1989; 256: 1-3.

8 Hirata Y, Yoshimi H, Takata S, Watanabe TX, Kumagai S Nakajima $\mathrm{K}$, et al. Cellular mechanism of action by nove vasoconstrictor endothelin in cultured rat vascular smooth muscle cells. Biochem Biophys Res Commun 1988; 154: 868-75.

9 Power RF, Wharton J, Zhao Y, Bloom SR, Polak JM. Autoradiographic localization of endothelin-1 binding sites in the cardiovascular and respiratory systems. $\mathcal{f}$ Cardiovasc Pharmacol 1989; 13: S50-6.

10 Kanse SM, Ghatei MA, Bloom SR. Endothelin binding sites in porcine aortic and rat lung membrane. Eur 7 Biochem 1989 ; porcine aor

11 Orita Y, Fujiwara Y, Ochi S, Takama T, Fukunaga M, Yokoyama K. Endothelin-1 receptors in rat renal glomeruli. Cardiovasc Pharmacol 1989; 13: S159-61.

12 Jones CR, Hiley CR, Pelton JT, Mohi M. Autoradiographic visualization of the binding sites for [ $\left.{ }^{125} \mathrm{I}\right]$ endothelin in rat and human brain. Neurosci Lett 1989; 97: 276-9.

13 Koseki C, Imai M, Hirata Y, Yanagisawa M, Masaki T. Autoradiographic distribution in rat tissues of binding sites for endothelin: a neuropeptide? Am J Physiol 1989; 256: R858-66.

14 Yoshizawa T, Shinmi O, Giaid A, Yanagisawa M, Gibson SJ, Kimura S, et al. Endothelin: a novel peptide in the posterior pituitary system. Science 1990; 247: 462-4.
15 Yoshizawa T, Kimura S, Kanazawa S, Kanazawa I, Uchiyama $\mathrm{Y}$, Yanagisawa M, et al. Endothelin localizes in the dorsal horn and acts on the spinal neurones: possible involvement of dihydropyridine-sensitive calcium channels and subof dihydropyridine-sensitive calcium channels

16 Shinmi O, Kimura S, Yoshizawa T, Sawamura T, Uchiyam $\mathrm{Y}$, Sugita Y, et al. Presence of endothelin-1 in porcine spinal cord: isolation and sequence determination. Biochem Biophys Res Commun 1989; 162: 340-6.

17 Giaid A, Gibson SJ, Nassif BN, Ibrahim N, Legon S, Bloom $\mathrm{SR}$, et al. Endothelin-1, an endothelium-derived peptide, is expressed in neurons of the human spinal cord and dorsal root ganglia. Proc Natl Acad Sci USA 1989; 86: 7634-8.

18 MacCumber MW, Ross CA, Snyder SH. Endothelin in brain: receptors, mitogenesis and biosynthesis in glial cells. Proc Natl Acad Sci USA 1990; 87: 2359-63.

19 Suyattapone S, Simpson AWM, Ashley CC. Free calcium rise and mitogenesis in glial cells caused by endothelin. Biochem Biophys Res Commun 1989; 165: 1115-22.

20 Lee ME, de la Monte SM, Ng SC, Bloch KD, Quertermous T Expression of the potent vasoconstrictor endothelin-1 in the human central nervous system. F Clin Invest 1990; 86: $141-4$

21 Inagaki $\mathrm{H}$, Bishop AE, Escrig C, Wharton J, Yura J, AllenMersh TG, et al. Neural endothelin-like immunoreactivity and endothelin binding sites in human colon. Gastroenterology 1991; 101 : 47-54.

22 Huang WM, Gibson SJ, Facer P, Gu J, Polak JM. Improved section adhesion for immunocytochemistry using high molecular weight polymers of L-lysine as a slide coating. Histochem f 1983; 77: 275-9.

23 Hsu SM, Raine L, Fanger $\mathrm{H}$. Use of avidin-biotin-peroxidase complex $(\mathrm{ABC})$ in immunoperoxidase techniques: a comparison between $\mathrm{ABC}$ and unlabelled antibody (PAP) proparison between $\mathrm{ABC}$ and unlabelled antibody

24 Facer P, Bishop AE, Lloyd RV, Wilson BS, Hennessey RJ Polak JM. Chromogranin: a newly recognised marker for endocrine cells of the human gastrointestinal tract. Gastroenterology 1985; 89: 1366-73.

25 Su HC, Bishop AE, Power RF, Hamada Y, Polak JM. Dual intrinsic and extrinsic origins of CGRP- and NPY-immunoreactive nerve of rat gut and pancreas. 7 Neurosci 1987; 7 2674-87.

26 Bryant MG, Bloom SR. Measurement in tissues. In: Bloom SR, Long RG, ed. Radioimmunoassay of gut regulatory peptides. London: Saunders, 1982: 36-41.

27 Takahashi K, Jones PM, Kanse SM, Laui HC, Spokes RA Ghatei MA, et al. Endothelin in the gastrointestinal tract: presence of endothelin-like immunoreactivity, endothelin-1 presence of endothelin-like immunoreactivity, endothelin-1 mRNA, endothelin receptors and

28 Fabregat I, Rozengurt E. Vasoactive intestinal contractor, a novel peptide, shares a common receptor with endothelinand stimulates $\mathrm{Ca}^{2+}$ mobilization and DNA synthesis in Swiss 3T3 cells. Biochem Biophys Res Comm 1990; 167 161-7.

29 Hirata Y, Takagi Y, Fukuda Y, Marumo F. Endothelin is a potent mitogen for rat vascular smooth muscle cells. Atherosclerosis 1989; 78: 225-8.

30 Sawamura T, Kimura S, Shinmi O, Sugita Y, Yanagisawa M, Masaki T. Analysis of endothelin related peptides in culture supernatant of porcine aortic endothelial cells: evidence supernatant of porcine aortic endothelial cells: evidence
biosynthetic pathway of endothelin-1. Biochem Biophys Res biosynthetic pathway of endo 